Article

\title{
Impacts of Phosphogypsum, Soluble Fertilizer and Lime Amendment of Acid Soils on the Bioavailability of Phosphorus and Sulphur under Lucerne (Medicago sativa)
}

\author{
Moussa Bouray ${ }^{1,2, *(\mathbb{D}}, \operatorname{Jim}$ Moir ${ }^{1}\left(\mathbb{D}\right.$, Leo Condron ${ }^{1}$ and Niklas Lehto ${ }^{1}(\mathbb{D}$ \\ 1 Department of Soil Science, Lincoln University, Lincoln 7647, Christchurch, New Zealand; \\ Jim.Moir@lincoln.ac.nz (J.M.); Leo.Condron@lincoln.ac.nz (L.C.); Niklas.Lehto@lincoln.ac.nz (N.L.) \\ 2 AgroBioSciences Program, Mohammed VI Polytechnic University (UM6P), Benguerir 43150, Morocco \\ * Correspondence: moussa.bouray@lincolnuni.ac.nz; Tel.: +64-22-398-9124
}

Received: 16 June 2020; Accepted: 9 July 2020; Published: 13 July 2020

\begin{abstract}
Legumes play critical dual roles in grazed grassland ecosystems; providing nitrogen inputs and high-quality feed for grazing livestock. However, many species fail to persist in acidic, low fertility soils. A glasshouse study was conducted to investigate the response of lucerne (Medicago sativa) to phosphogypsum (PG), lime and soluble $\mathrm{P}+\mathrm{S}$ fertilizer (PS) application to two soils. Phosphorus and sulphur were applied through either PG $\left(0,1,3\right.$ and $\left.9 \mathrm{tha}^{-1}\right)$ or $\mathrm{P}+\mathrm{S}$ fertilizer at equivalent rates to $\mathrm{PG}$. Both PG and PS were applied with or without lime, which was applied at $2 \mathrm{t} \mathrm{ha}^{-1}$. Yield and nutrient uptake of the lucerne was measured, while the soil was analyzed for $\mathrm{pH}$, Olsen $\mathrm{P}$ and exchangeable aluminum. Yield responses were significantly different between the two soils. Maximum yields and $\mathrm{P}$ and $\mathrm{S}$ uptakes were obtained under PG $9 \mathrm{t} \mathrm{ha}^{-1}$ combined with lime. Exchangeable Al decreased in both soils under $1 \mathrm{ha}^{-1}$ of PG compared with the control. At the highest rate, Olsen P increased by 8 and $6 \mathrm{mg} \mathrm{kg}^{-1}$ for PG and by 6 and $11 \mathrm{mg} \mathrm{kg}^{-1}$ for PS compared with the control for Glenmore and Molesworth soils respectively. Phosphogypsum showed positive effects on $\mathrm{P}$ and $\mathrm{S}$ bioavailability.
\end{abstract}

Keywords: lucerne; acid soil; phosphogypsum; phosphorus; sulphur; exchangeable aluminum

\section{Introduction}

Soil acidity coupled with phytotoxic concentrations of soil exchangeable aluminum (Al) and low phosphorus (P) and very low sulphur (S) availability are among the major limitations to legume establishment and growth in New Zealand hill and high country farms [1-3]. Lucerne (Medicago sativa) is one of the most valuable forage legumes in New Zealand but is very sensitive to aluminum (Al) and manganese [4] toxicities that prevail in low $\mathrm{pH}[5,6]$ and $\mathrm{P}$ availability [3]. Hence the lime application is often an essential prerequisite to counteract soil acidity and enhance legume establishment and persistence in grasslands [7]. However, liming effectiveness is limited to the shallow top-soil layer and has a very limited effect on subsoil acidity in the short term [8] due to its low solubility and passive movement down the soil profile $[9,10]$.

Most productive pasture legumes are adapted to highly fertile soils [1]. In contrast, soil fertility levels (plant-available P and S) are often low in many hill and high country soils in New Zealand [2] due to low fertilizer inputs [11] which is driven by the economics of fertilizer and lime application in these complicated topographical areas requiring aerial application [12]. As such, the sustainability of legume production in New Zealand hill and high-country pastures may depend on new alternative affordable sources of nutrients for the farmers. 
Phosphogypsum (PG), a by-product of the phosphoric fertilizer industry, is produced when rock phosphate (fluorapatite) is digested with concentrated sulphuric acid according to the following chemical formula:

$$
\mathrm{Ca}_{10}\left(\mathrm{PO}_{4}\right)_{6} \mathrm{~F}_{2}+10 \mathrm{H}_{2} \mathrm{SO}_{4}+20 \mathrm{H}_{2} \mathrm{O} \leftrightarrow 6 \mathrm{H}_{3} \mathrm{PO}_{4}+10 \mathrm{CaSO}_{4} \cdot 2 \mathrm{H}_{2} \mathrm{O}+2 \mathrm{HF} .
$$

About 160 million tons of phosphogypsum are produced annually worldwide and it is mainly disposed of in large stockpiles or discharged in water bodies [13]. It contains predominantly sulphur and calcium oxide and small amounts of phosphorus [14]. It may contain small amounts of heavy metals and radioactive element impurities, whose concentrations depend on the composition of raw materials $[15,16]$ and the processing method used [17]. Because of these impurities, the use of PG has been restricted in some markets, although these restrictions did not always have a proper scientific justification [13].

Phosphogypsum is used in agriculture all over the world, for example in Brazil, Spain, Australia, India, Pakistan, USA and Egypt [18-20], either as soil amendment under the category "Calcium sulphate" or as fertilizer [21]. Several benefits of PG application in agriculture have been reported worldwide for saline/sodic soils [22-24] or acidic soils [25-28]. However, research on PG application on acid soils has mostly focused on its effects in alleviating the toxic effects of high Al bioavailability or used in providing calcium for crops [27]. Studies examining PG effects on soil fertility in general and on $\mathrm{P}$ and $\mathrm{S}$ availability in acid soils $(\mathrm{pH} \leq 5)$ for legumes are limited; to date, there has been no research on PG use in NZ grasslands.

The main objective of this study was to compare the effects of PG amendment, soluble fertilizer and lime on short-term lucerne yield and $\mathrm{P}$ and $\mathrm{S}$ uptake in two different acid soils under controlled environment conditions.

\section{Results}

\subsection{Phosphogypsum Effects on Yield and Nutrient Uptake}

Plant response to soil inputs varied depending on the soil type and treatment type and rate (Figures 1 and 2). Total dry matter (TDM) yields were different $(p<0.001)$ between the two soils, an average of $1.2 \mathrm{~g}$ and $3.2 \mathrm{~g}$ TDM yield per pot were recorded for Molesworth (MO) and Glenmore (GM) soils respectively, across all treatments. Likewise, the main effect of liming and phosphogypsum (PG) was significant on TDM yield per pot. However, the soluble fertilizer's (PS) main effect was not significant (Table 1). Moreover, the effect of the interaction on the TDM yield was only significant for soil $\times$ PG (Figure 1). As such, the significance of the simple effect of PG was presented for GM and MO separately under the two lime rates (Figure 2).

At the highest tested rate, R3 $=9 \mathrm{tha}^{-1}$, the PG increased $(p<0.01)$ the TDM yield compared to the control (R0) in the unlimed MO soils (Figure 2a), whilst at the rates of $\left(R 1=1 \mathrm{ha}^{-1}\right)$ and $\left(\mathrm{R} 2=3 \mathrm{tha} \mathrm{h}^{-1}\right)$, the yields were lower and no significant effects were recorded compared to the control. Whereas, in unlimed GM soil, the PG $\left(9 \mathrm{tha}^{-1}\right)$ effect on the yield was not significant compared to the control unless combined with lime. The yields were greater in the presence of lime for both PG and PS application. Phosphogypsum at R3 $\left(9 \mathrm{tha}^{-1}\right)$ combined with lime $\left(2 \mathrm{t} \mathrm{ha}^{-1}\right)$ increased TDM yield in the order of $46 \%$ and $77 \%$ compared with PG $\left(9 \mathrm{t} \mathrm{ha}^{-1}\right)$ alone for GM and MO respectively. Similarly, soluble fertilizer applied at the same rates of $S$ and $P$ and combined with lime (R3 + Lime), increased the yield by $20 \%$ and $91 \%$ compared to PS (R3) alone for MO and GM respectively.

The comparison between PG and PS in terms of TDM yields generated per rate under the two investigated soils and lime rates are shown in Figure 2. Trends in dry matter yields were relatively similar for PG and soluble fertilizer (PS) treatments in MO soil (Figure 2a); the yields increased proportionally to the application rate. However, where lime was added, an opposite trend was observed between PG and PS for GM soil (Figure 2b). In most cases, the average TDM yield produced per rate were not different $(p>0.05)$ between PG and PS regardless of soil and lime effects, except for 
R3 under unlimed MO and R3 under limed GM where PG effect was significantly $(p<0.01)$ higher compared to PS.

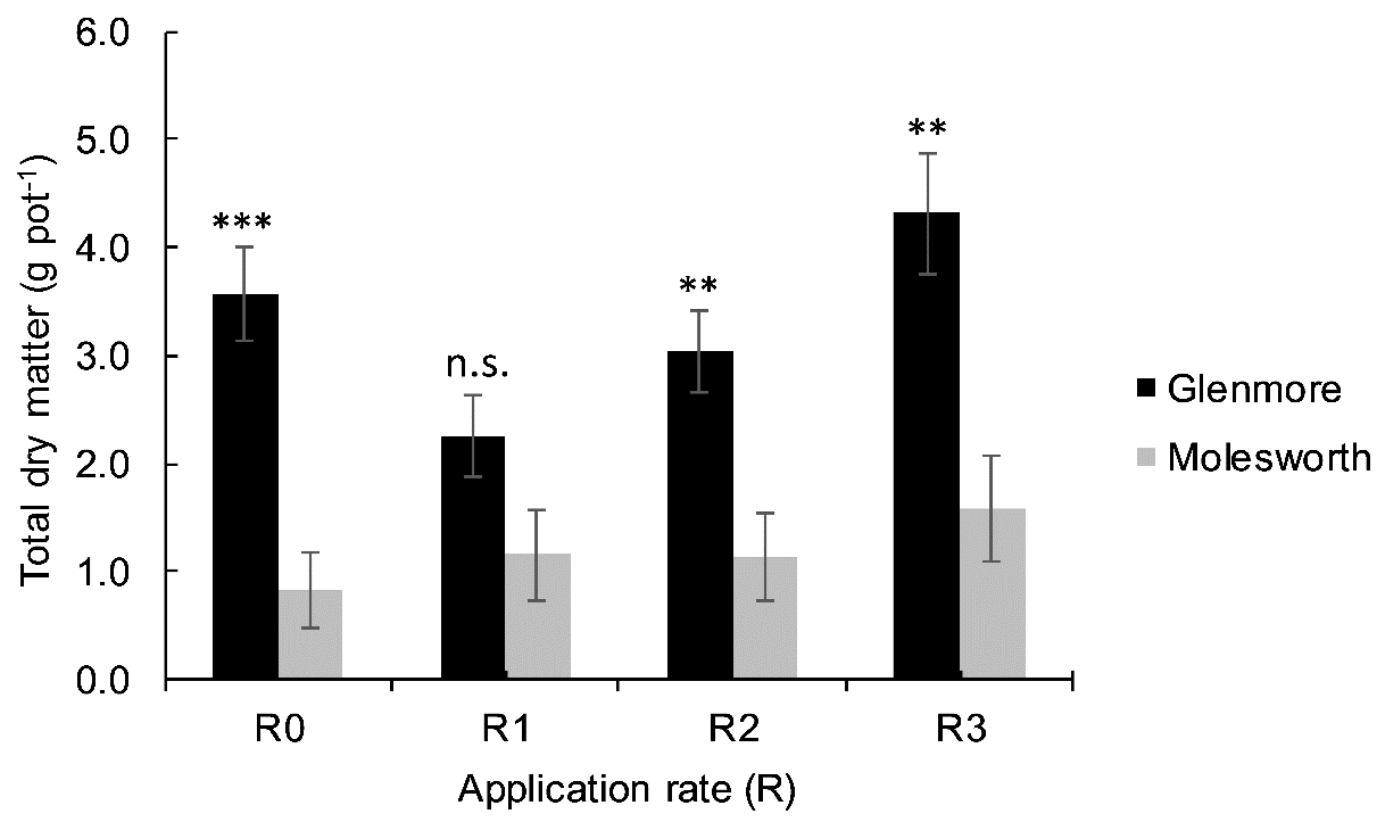

Figure 1. Total dry matter yield ( $\mathrm{g} \mathrm{pot}^{-1}, \mathrm{n}=8$ ) of lucerne (Medicago sativa) after six-month growth period under two different soils: Molesworth (MO) and Glenmore (GM), as affected by four rates of phosphogypsum (PG) across two lime treatments $\left(0\right.$ and $\left.2 \mathrm{t} \mathrm{ha}^{-1}\right)$. Error bars indicate standard errors ( \pm SEM, $n=8$ ). Means of TDM for GM and MO per rate (R0 to R3) were separated using a two-sample $t$-test at $5 \%$. Asterisks above bars indicate the level of significance in the difference between the two soils within each rate of PG $\left({ }^{* *} p<0.01,{ }^{* * *} p<0.001\right.$, n.s. not significant).

Table 1. Summary of the analyses of variance to evaluate the effect of soil type, lime and phosphogypsum (PG) or soluble fertilizer (PG) and their interactions on total dry matter yield of lucerne (TDM, g pot ${ }^{-1}$ ).

\begin{tabular}{ccc}
\hline Factors & Phosphogypsum (PG) & Soluble Fertilizer (PS) \\
\hline Soil (S) & $* * *$ & $* * *$ \\
Lime (L) & $* * *$ & $* * *$ \\
Rate (R) & $* * *$ & n.s. \\
$S^{*} \mathrm{~L}$ & n.s. & n.s. \\
$\mathrm{S}^{*} \mathrm{R}$ & $* *$ & n.s \\
$\mathrm{L}^{*} \mathrm{R}$ & n.s. & n.s \\
$\mathrm{S}^{*} \mathrm{~L}^{*} \mathrm{R}$ & n.s. & n.s
\end{tabular}

Asterisks indicate significant effect levels $\left({ }^{*} p<0.05,{ }^{* *} p<0.01,{ }^{* * *} p<0.001\right)$, n.s. not significant.

For the MO soil, most of the treatments without lime did not result in enough shoot dry matter for herbage analysis; the quantities harvested were less than $0.2 \mathrm{~g}$ which is the minimum required shoot weight for nutrients analysis through digestion solution, thus data of $\mathrm{P}$ and $\mathrm{S}$ uptakes were not determined. Shoots of the plants grown on limed GM soil showed higher P and S uptakes than those grown on limed MO soil. Significant treatment effects were recorded for the two soils regarding $S$ uptake (Table 2). The highest S uptakes were found under PS (R3) and PG (R3) both combined with lime irrespective of soil type, though PG (R3) either combined with lime or not significantly enhanced $\mathrm{S}$ uptake compared with the control under GM soil. For $\mathrm{P}$, the highest uptakes were recorded under PG (R3) combined with lime regardless of soil type. For example, under limed GM soil, PG (R3) increased $(p<0.05)$ P uptake by $35 \%$ compared to PS (R3) and by $21 \%$ compared with the control (R0). However, without lime addition, PG's effect on nutrient uptake, particularly P, was similar to PS. 

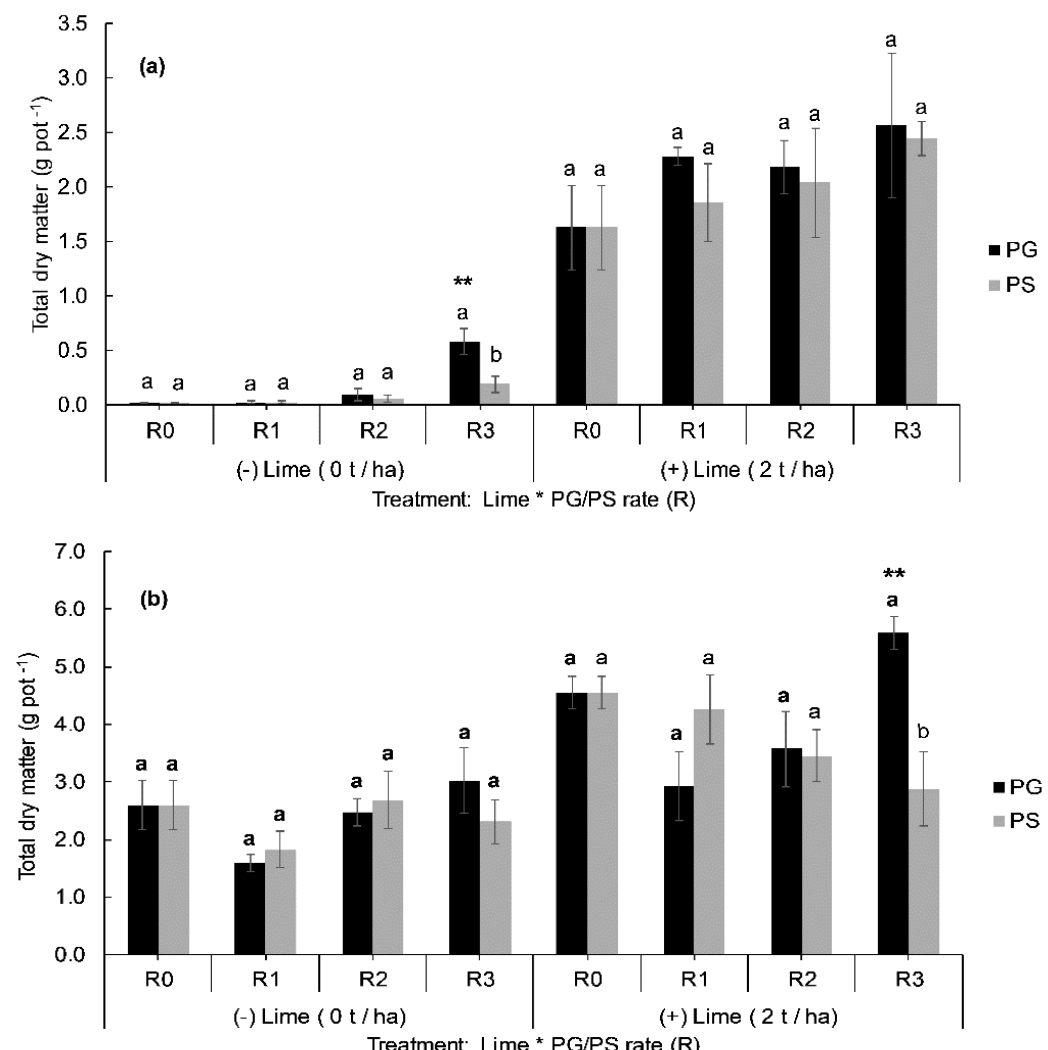

Figure 2. Comparison between the effects of phosphogypsum (PG) and soluble fertilizer (PS) on total dry matter yield ( $\mathrm{g} \mathrm{pot}^{-1}, \mathrm{n}=4$ ) of lucerne (Medicago sativa) after six month growth period under two different soils: Molesworth (a) and Glenmore (b) treated (+) or not (-) with lime. Error bars indicate standard errors ( \pm SEM, $\mathrm{n}=4$ ). Means of TDM for PG and PS per rate (R0 to R3) were separated using a two-sample $t$-test at $5 \%$, means indicated by the same lower-case letter per rate are not significantly different. Asterisks above bars indicate the application rate where TDM was significantly higher compared to the corresponding control under PG and PS separately, according to the Dunnett test at $5 \%$. ${ }^{* *}$ indicates a one-way ANOVA significance level (1\%).

Table 2. The effects of phosphogypsum (PG), soluble fertilizer (PS) and lime on lucerne (Medicago sativa) shoot $\mathrm{P}$ and $\mathrm{S}$ uptakes from Glenmore and Molesworth soils after a six-month plant growth period. Within rows, means followed by the same lower-case letter are not significantly different (Dunnett test at $5 \%, \mathrm{R} 0=$ control). Within columns, means were compared using a two-sample $t$-test at $5 \%$.

\begin{tabular}{|c|c|c|c|c|c|c|c|c|c|c|c|}
\hline & & \multicolumn{5}{|c|}{ P Uptake (mg pot ${ }^{-1}$ ) } & \multicolumn{5}{|c|}{ S Uptake (mg pot $\left.{ }^{-1}\right)$} \\
\hline & & R0 & R1 & R2 & R3 & $p$ Value $\ddagger$ & R0 & R1 & $\mathbf{R} 2$ & R3 & $p$ Value \\
\hline \multicolumn{12}{|c|}{ Glenmore (GM) } \\
\hline \multirow[t]{2}{*}{ (-) Lime } & Soluble fertilizer & 3.76 & 2.79 & 3.78 & 2.87 & n.s. & 4.55 & 4.57 & 5.71 & 7.69 & n.s. \\
\hline & $p$ value $^{\dagger}$ & n.s. & n.s. & n.s. & n.s. & & n.s. & n.s. & n.s. & n.s. & \\
\hline (+) Lime & Phosphogypsum & 4.44 & 3.73 & 4.61 & 5.65 & n.s. & $5.92 a$ & $5.79 a$ & $7.72 \mathrm{a}$ & $9.77 b$ & $<0.001^{* * *}$ \\
\hline \multicolumn{12}{|c|}{ Molesworth (MO) } \\
\hline \multirow{3}{*}{ (-) Lime } & Phosphogypsum & n.d. & n.d. & n.d. & 0.50 & N.A. & n.d. & n.d. & n.d. & 1.33 & N.A. \\
\hline & Soluble fertilizer & n.d. & n.d. & n.d. & n.d. & N.A. & n.d. & n.d. & n.d. & n.d. & N.A. \\
\hline & $p$ value & N.A. & N.A. & N.A. & N.A. & & N.A. & N.A. & N.A. & N.A. & \\
\hline (+) Lime & Phosphogypsum & 1.43 & 2.08 & 2.26 & 2.52 & 0.053 n.s. & $1.97 \mathrm{a}$ & $3.46 a$ & $3.86 \mathrm{~b}$ & $5.36 \mathrm{~b}$ & $0.001 * *$ \\
\hline
\end{tabular}

Asterisks indicate significant effect levels $\left({ }^{*} p<0.05,{ }^{* *} p<0.01,{ }^{* * *} p<0.001\right)$. N.A. not applicable, n.d. not determined, n.s. not significant, ${ }^{\ddagger}$ One-way ANOVA at $5 \%,{ }^{\dagger}$ two-sample $t$-test at $5 \%$. 
The multiple linear regression analysis results are presented in Table 3. The data of PG and PS treatments were compiled to conduct this analysis $(n=128)$. The comparison of standardized coefficients for the three considered variables $(\mathrm{pH}$, exchangeable $\mathrm{Al}$ and Olsen $\mathrm{P}$ ) revealed that $\mathrm{pH}$ was the most important factor in impacting the TDM yield followed by Olsen $\mathrm{P}$, then exchangeable aluminum. The interaction between these three predictors was not significant, therefore excluded from the model. The regression equation is presented below:

$$
\begin{gathered}
\text { TDM yield }=-13.20+2.89 \mathrm{pH}_{\mathrm{CaCl} 2}+0.042 \text { Exchangeable } \mathrm{Al}+0.082 \text { Olsen } \mathrm{P} \\
\left(\mathrm{n}=128, p<0.001, \text { Adjusted } \mathrm{R}^{2}=25 \%\right)
\end{gathered}
$$

Table 3. Multiple linear analysis regression results (coded coefficients).

\begin{tabular}{cccccc}
\hline & Standardized Coefficients & SE Coefficients & $\boldsymbol{t}$ Value & $\boldsymbol{p}$ Value & VIF \\
\hline Constant & 2.15 & 0.13 & 16.63 & $p<0.001$ & \\
$\mathrm{pH}\left(\mathrm{CaCl}_{2}\right)$ & 0.70 & 0.14 & 5.08 & $p<0.001$ & 1.14 \\
Exchangeable Al & 0.31 & 0.16 & 2.01 & 0.047 & 1.45 \\
Olsen P & 0.40 & 0.15 & 2.55 & 0.012 & 1.43 \\
\hline
\end{tabular}

VIF variance inflation factor, $\mathrm{SE}$ standard error.

\subsection{Phosphogypsum Effects on Soil $\mathrm{pH}$, Olsen $\mathrm{P}$ and Exchangeable Aluminum}

Soil $\mathrm{pH}$ and exchangeable $\mathrm{Al}$ concentrations in both soils changed during the six-month growth period (Tables 4 and 5). There were decreases in both $\mathrm{pH}\left(\mathrm{H}_{2} \mathrm{O}\right)$ and $\mathrm{pH}\left(\mathrm{CaCl}_{2}\right)$ between the highest and lowest PG application rates in the GM soil and for the $\mathrm{pH}\left(\mathrm{H}_{2} \mathrm{O}\right)$ in the $\mathrm{MO}$ soil, while the $\mathrm{pH}$ $\left(\mathrm{CaCl}_{2}\right)$ in the $\mathrm{MO}$ soil was relatively stable. Adding lime increased the $\mathrm{pH}$ of both soils and while the PG treatments mostly negated this effect at the highest rate, the lime generally reduced the acidifying effect of increasing PG application rate. When lime was applied, a significant decrease in $\mathrm{pH}$ was seen in the $\mathrm{pH}\left(\mathrm{H}_{2} \mathrm{O}\right)$ of both soils between the highest and lowest PG application rates. Another notable exception was the $\mathrm{pH}\left(\mathrm{CaCl}_{2}\right)$ in the $\mathrm{MO}$ soil, where the effect of the lime was comparatively similar across the four levels of PG. The PS treatments did not significantly change the $\mathrm{pH}\left(\mathrm{H}_{2} \mathrm{O}\right)$ of the soils. Further, an increase $(p<0.05)$ in $\mathrm{pH}\left(\mathrm{CaCl}_{2}\right)$ was observed at the highest rate ( $\left.\mathrm{R} 3\right)$ compared with the corresponding controls for limed GM and unlimed MO soils.

Exchangeable aluminum concentrations under different treatments in both soils exceeded the toxicity threshold of $3 \mathrm{mg} \mathrm{kg}^{-1}$ [3] for most grassland legume species. However, a substantial decrease of exchangeable $\mathrm{Al}$ content was observed for some treatments. For example, 5.9 and $7.5 \mathrm{mg} \mathrm{kg}^{-1}$ decrease of exchangeable $\mathrm{Al}$ concentration in GM and MO respectively were found under limed control (R0) compared with the unlimed control. A decrease of 5.3 and $2.4 \mathrm{mg} \mathrm{kg}^{-1}$ of exchangeable Al was recorded in unlimed GM and MO soils respectively at R1 $=1 \mathrm{tha}^{-1}$ of PG compared with the corresponding controls, also a reduction of $5.7 \mathrm{mg}$ of exchangeable aluminum per $\mathrm{kg}$ of unlimed $\mathrm{MO}$ soil at R2 (3 t PG ha ${ }^{-1}$ ) compared with the corresponding control was observed. Whereas, at R3 (9 t PG $\mathrm{ha}^{-1}$ ) the soil exchangeable aluminum increased in both soils. The same effect has been observed for soluble fertilizer PS (R3) in both soils but PS was less effective in reducing soil exchangeable $\mathrm{Al}$ at low rates (R1 and R2) compared to PG; a decrease of $2.9 \mathrm{mg} \mathrm{kg}^{-1}$ was observed for PS (R1) in the unlimed GM soil only. The exchangeable $\mathrm{Al}$ concentrations were relatively higher across all PS treatments compared to PG treatment in the absence of lime.

The relationships between PG and PS treatments and soil Olsen P are presented in Figure 3. The Olsen P measured in both soils increased $(p<0.05)$ in the presence of PG with a maximum recorded at $9 \mathrm{t}$ PG ha- 1 where Olsen $P$ increase by 8 and $7 \mathrm{mg} \mathrm{kg}^{-1}$ compared with the control $\left(0 \mathrm{t} \mathrm{ha}^{-1}\right)$ for $\mathrm{MO}$ and GM soils respectively. Similarly, PS increased $(p<0.05)$ Olsen P by 6 and $11 \mathrm{mg} \mathrm{kg}^{-1}$ at the highest rate $\left(198 \mathrm{~kg} \mathrm{MCP} \mathrm{ha}^{-1}\right)$ compared with the control $\left(0 \mathrm{~kg} \mathrm{MCP} \mathrm{ha}^{-1}\right)$ for MO and GM soils respectively. The average Olsen P across all treatments of PG or PS was higher $(p<0.05)$ in GM soil compared to $\mathrm{MO}$ soil for both 0 and $2 \mathrm{t}$ lime ha ${ }^{-1}$ (Table 6). The average Olsen $\mathrm{P}$ across all PG rates decreased under 
liming in both soils but to a lesser extent compared to PS. For example, in limed GM soil, the average Olsen P for PG decreased by $0.9 \mathrm{mg} \mathrm{kg}^{-1}$ compared to the unlimed GM. However, for PS the decrease was 5 times higher than that of PG. A similar trend was observed in the limed MO soil compared to unlimed MO, though the difference between PG and PS is not as large as in GM soil.

Table 4. Effects of phosphogypsum and soluble fertilizer on soil $\mathrm{pH}$ (water and $\mathrm{CaCl}_{2}$ ) and exchangeable aluminum in both Glenmore and Molesworth soils under no lime application, after six months plant growth period. Within rows, means followed by the same lower-case letter are not significantly different (Dunnett test at 5\%, R0 = control). Within columns, means were compared using a two-sample $t$-test at $5 \%$.

\begin{tabular}{|c|c|c|c|c|c|c|c|c|c|c|}
\hline & \multicolumn{5}{|c|}{ Phosphogypsum (PG) } & \multicolumn{5}{|c|}{ Soluble Fertilizer (PS) } \\
\hline & R0 & R1 & $\mathbf{R} 2$ & R3 & $p$ Value $\ddagger$ & R0 & R1 & $\mathbf{R} 2$ & R3 & $p$ Value \\
\hline \multicolumn{11}{|l|}{$\mathrm{pH}$ water } \\
\hline Glenmore (GM) & $4.84 \mathrm{a}$ & $4.82 \mathrm{a}$ & $4.63 a$ & $4.42 b$ & $0.037 *$ & 4.84 & 5.03 & 5.00 & 4.86 & n.s. \\
\hline Molesworth (MO) & 4.83 & 4.66 & 4.59 & 4.49 & n.s & 4.83 & 4.81 & 4.80 & 4.82 & n.s. \\
\hline$p$ value $^{\dagger}$ & n.s. & n.s & n.s. & n.s. & & n.s. & 0.041 * & n.s. & n.s. & \\
\hline Glenmore (GM) & 4.47 & 4.39 & 4.31 & 4.23 & n.s. & 4.47 & 4.38 & 4.41 & 4.46 & n.s. \\
\hline Molesworth (MO) & 4.16 & 4.24 & 4.30 & 4.31 & n.s. & $4.16 \mathrm{a}$ & $4.33 b$ & $4.30 \mathrm{a}$ & $4.43 b$ & $0.006^{* *}$ \\
\hline$p$ value & n.s. & $0.040 *$ & n.s. & n.s. & & n.s. & n.s. & n.s. & n.s. & \\
\hline \multicolumn{11}{|c|}{ Exchangeable $\mathrm{Al}\left(\mathrm{mg} \mathrm{kg}^{-1}\right)$} \\
\hline
\end{tabular}

Asterisks indicate significant effect levels $\left({ }^{*} p<0.05,{ }^{* *} p<0.01\right.$, n.s. not significant). R0 to R3 indicates the four rates of PG $\left(0,1,3\right.$ and $\left.9 \mathrm{tha}^{-1}\right)$ and their equivalence for PS. $\ddagger$ One-way ANOVA at $5 \%$; ${ }^{\dagger}$ two-sample $t$-test at $5 \%$.

Table 5. Effects of phosphogypsum and soluble fertilizer on $\mathrm{pH}$ (water and $\mathrm{CaCl}_{2}$ ) and exchangeable aluminum in Glenmore and Molesworth soils under liming $\left(2 \mathrm{tha}^{-1}\right)$ conditions. Within rows, means followed by the same lower-case letter are not significantly different (Dunnett test at 5\%, R0 = control). Within columns, means were compared using a two-sample $t$-test at $5 \%$.

\begin{tabular}{|c|c|c|c|c|c|c|c|c|c|c|}
\hline & \multicolumn{5}{|c|}{ Phosphogypsum (PG) } & \multicolumn{5}{|c|}{ Soluble Fertilizer (PG) } \\
\hline \multicolumn{11}{|l|}{$\mathrm{pH}$ water } \\
\hline Glenmore (GM) & $5.26 a$ & $5.16 \mathrm{a}$ & $5.00 \mathrm{~b}$ & $4.66 \mathrm{~b}$ & $<0.001^{* * *}$ & 5.26 & 5.27 & 5.27 & 5.20 & n.s. \\
\hline Molesworth (MO) & $5.35 \mathrm{a}$ & $5.23 a$ & $5.03 \mathrm{~b}$ & $4.82 \mathrm{~b}$ & $<0.001^{* * *}$ & 5.35 & 5.33 & 5.33 & 5.32 & n.s. \\
\hline$p$ value $^{+}$ & n.s. & n.s. & n.s. & $\begin{array}{c}0.042 \\
*\end{array}$ & & n.s. & n.s. & $\begin{array}{c}0.018 \\
*\end{array}$ & n.s. & \\
\hline \multicolumn{11}{|l|}{$\mathrm{pHCaCl} \mathrm{CH}_{2}$} \\
\hline Glenmore (GM) & $4.64 \mathrm{a}$ & $4.74 \mathrm{a}$ & $4.73 a$ & $4.52 b$ & 0.011 * & $4.64 \mathrm{a}$ & $4.75 a$ & $4.80 \mathrm{a}$ & $4.86 \mathrm{~b}$ & 0.043 * \\
\hline Molesworth (MO) & 4.73 & 4.74 & 4.74 & 4.65 & n.s. & 4.73 & 4.76 & 4.82 & 4.88 & n.s. \\
\hline$p$ value & n.s. & n.s. & n.s. & $\begin{array}{l}0.045 \\
*\end{array}$ & & n.s. & n.s. & n.s. & n.s. & \\
\hline \multicolumn{11}{|c|}{ Exchangeable $\mathrm{Al}\left(\mathrm{mg} \mathrm{kg}^{-1}\right)$} \\
\hline$p$ value & n.s. & $0.026 *$ & n.s. & n.s. & & n.s. & n.s. & n.s. & n.s. & \\
\hline
\end{tabular}

Asterisks indicate significant effect levels $\left({ }^{*} p<0.05,{ }^{* *} p<0.01, * * * p<0.001\right.$, n.s. not significant). R0 to R3 indicates the four rates of PG $\left(0,1,3\right.$ and $\left.9 \mathrm{t} \mathrm{ha}^{-1}\right)$ and their equivalence for PS. ${ }^{\ddagger}$ One-way ANOVA at $5 \%,{ }^{\dagger}$ two-sample $t$-test at $5 \%$. 

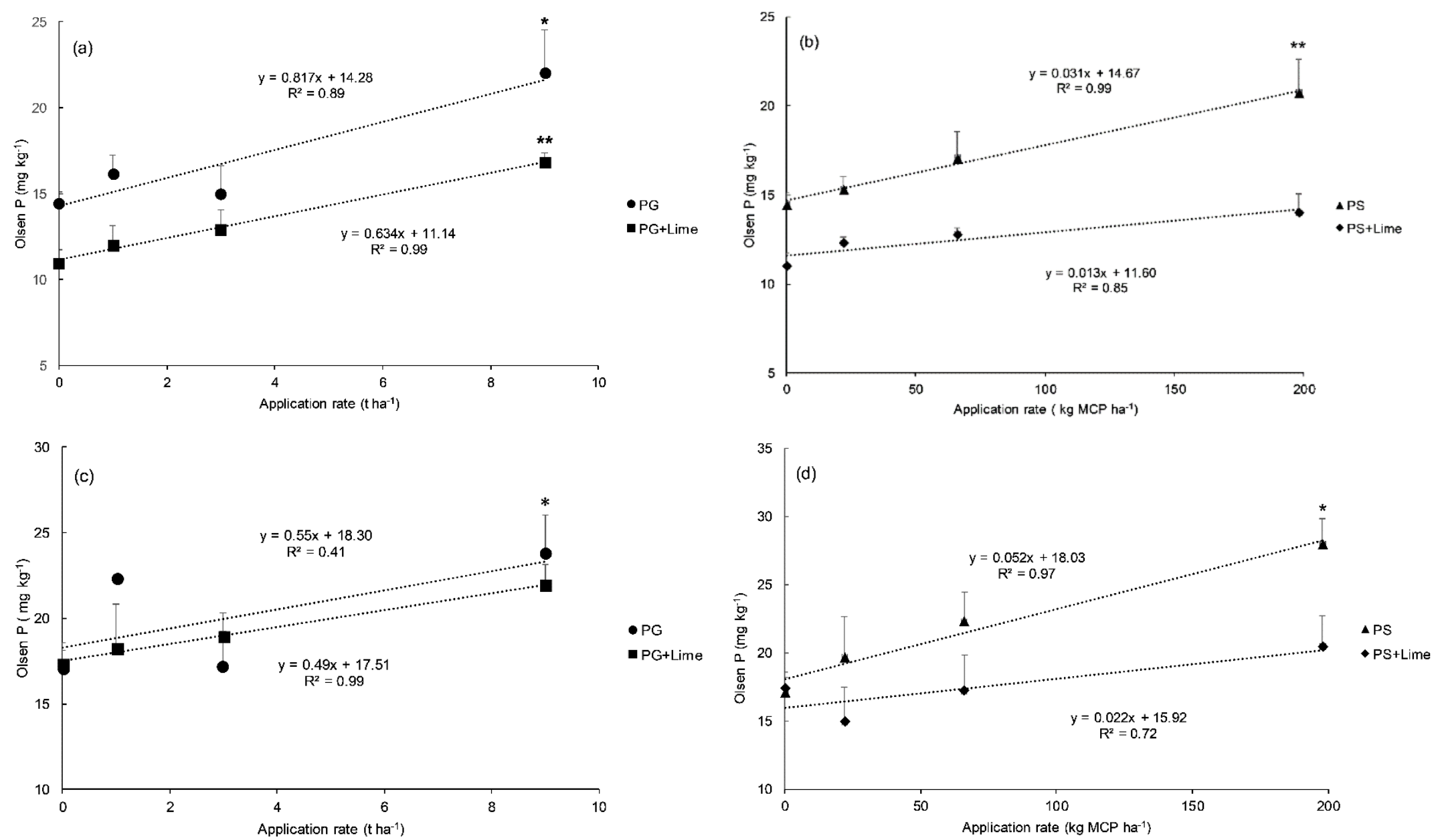

Figure 3. The relationship between mean Olsen $\mathrm{P}\left(\mathrm{mg} \mathrm{kg}^{-1}, \mathrm{n}=4\right)$ and application rate of phosphogypsum $\left.\left(\mathrm{PG}, \mathrm{tha}{ }^{-1}\right)\right)$ and soluble fertilizer $\left(\mathrm{PS}, \mathrm{kg}\right.$ of $\mathrm{MCP}$ ha $\left.{ }^{-1}\right)$ combined or not with lime under Molesworth $(\mathbf{a}, \mathbf{b})$ and Glenmore $(\mathbf{c}, \mathbf{d})$ soils, separately. Error bars indicate upper standard errors $(\mathrm{SEM}, \mathrm{n}=4)$. MCP: mono-calcium phosphate $\left(\mathrm{CaHPO}_{4}\right)$. Asterisks indicate the application rates which are significantly different from the control $\left(0\right.$ tons or $0 \mathrm{~kg}$ ha $\left.{ }^{-1}\right)$, according to the Dunnett test at $5 \%$. ${ }^{*}$ and ${ }^{* *}$ indicate a one-way ANOVA significance level of 5 and $1 \%$ 
Table 6. Average soil Olsen $\mathrm{P}\left(\mathrm{mg} \mathrm{kg}^{-1} \pm \mathrm{SEM}\right)$ measured after 6 months of phosphogypsum (PG), soluble fertilizer (PS) and lime application to two different soils (Glenmore and Molesworth). Within columns, means followed by the same lower-case letter are not significantly different (Dunnett test at $5 \%$ ). Within rows, means were compared using a two-sample $t$-test at $5 \%$.

\begin{tabular}{|c|c|c|c|c|c|c|}
\hline & \multicolumn{3}{|c|}{ (-) Lime (0 t ha $\left.{ }^{-1}\right)$} & \multicolumn{3}{|c|}{ (+) Lime $\left(2 t h^{-1}\right)$} \\
\hline & Glenmore & Molesworth & $p$ Value $\ddagger$ & Glenmore & Molesworth & $p$ Value \\
\hline Control & $17.1 \pm 1.51 \mathrm{a}$ & $14.5 \pm 0.67 a$ & n.s. & $17.3 \pm 0.80 \mathrm{a}$ & $11.0 \pm 0.73 a$ & $0.002 * *$ \\
\hline Phosphogypsum & $20.0 \pm 1.10 \mathrm{a}$ & $16.9 \pm 1.06 a$ & 0.051 n.s. & $19.1 \pm 0.86 a$ & $13.2 \pm 0.70 \mathrm{~b}$ & $<0.001^{* * *}$ \\
\hline $\begin{array}{c}\text { Soluble fertilizer } \\
p \text { value }^{+}\end{array}$ & $\begin{array}{c}21.8 \pm 1.40 \mathrm{~b} \\
0.025^{*}\end{array}$ & $\begin{array}{c}16.9 \pm 0.85 a \\
\text { n.s. }\end{array}$ & $0.008^{* *}$ & $\begin{array}{c}17.5 \pm 1.1 \mathrm{a} \\
\text { n.s. }\end{array}$ & $\begin{array}{c}12.5 \pm 0.41 \mathrm{a} \\
0.044^{*}\end{array}$ & $<0.001 * * *$ \\
\hline
\end{tabular}

Asterisks indicate significant effect levels $\left({ }^{*} p<0.05,{ }^{* *} p<0.01,{ }^{* * *} p<0.001\right)$, n.s. not significant. ${ }^{\dagger}$ One-way ANOVA at $5 \%, \ddagger$ two-sample $t$-test at $5 \%$.

\section{Discussion}

\subsection{Phosphogypsum Effects on Yield and Nutrient Uptake}

The difference in TDM yields produced under MO and GM soils regardless of treatment type can be attributed to the initial soil fertility. Low soil $\mathrm{pH}$ coupled with high exchangeable $\mathrm{Al}$ in the MO soil prevented seedlings from germinating and establishing (TDM $=0 \mathrm{~g} \mathrm{pot}^{-1}$ for control), thus depressing the overall average TDM in that soil compared with GM. Despite showing a decrease in exchangeable $\mathrm{Al}$ at 1 and $3 \mathrm{tha}^{-1}$, PG effects on TDM yields were less efficient than lime alone even at high application rates independently of soil type. These findings support the evidence that reducing exchangeable $\mathrm{Al}$ without improving soil $\mathrm{pH}$ will not be sufficient for legumes to persist. Therefore, lime was more efficient as it significantly increased soil $\mathrm{pH}$ while reducing exchangeable aluminum, which was not the case for PG. However, the mixture PG + Lime enhanced dry matter yield better than lime alone due to the supply of P and S through PG application. These two elements are considered the most limiting edaphic requirement to legumes in NZ hill and high country farms [1,29] which is consistent with the highest DM yields being observed when PG + Lime or PS + Lime were applied to MO soil. However, under GM soil TDM yield response to PS and PG did not support this hypothesis, except for PG at the highest rate where a significant increase in the yield was observed compared to the control under liming conditions.

The response to PG + Lime or PS + Lime was more pronounced for the MO soil compared to the GM soil, presumably because of the low initial P and $\mathrm{S}$ content of $\mathrm{MO}$ soil. The $\mathrm{SO}_{4}{ }^{2-}-\mathrm{S}$ level of the GM soil was above $10-12 \mathrm{mg} \mathrm{S} \mathrm{kg}^{-1}$, which is the range for near-maximum pasture on hill and high country farms in NZ [30]. For the $\mathrm{MO}$ soil, $\mathrm{SO}_{4}{ }^{2-}-\mathrm{S}$ level was below that range and its initial Olsen P was 5 units lower than GM. Additionally, the poor response to PS and PG in the unlimed GM soil compared to unlimed MO soil in terms of TDM yield could also be due to the exhibited higher Al bioavailability. For example, the drop in TDM yield observed at PS (R3) under unlimed GM soil was coincided with a significantly higher exchangeable $\mathrm{Al}$ concentration compared to the rest of the PS treatments.

The improvement of TDM yield under limed GM at PG (R3) against PS (R3) is supported by the significantly higher P uptake and higher S uptake for PG (R3) compared to PS (R3). This was in agreement with the difference in Olsen $\mathrm{P}$ concentration between the two treatments $(\triangle \mathrm{Olsen}$ $\mathrm{P}=1.5 \mathrm{mg} \mathrm{kg}^{-1}$ ) even though PS (R3) has greatly increased Olsen P compared to PG (R3) in the absence of lime ( $\Delta$ Olsen $\mathrm{P}=4 \mathrm{mg} \mathrm{kg}^{-1}$ ) for the same soil. These findings suggest that the depressive effect of lime on P availability is higher for PS than PG. Moreover, at R3 $\left(9 \mathrm{tha}^{-1}\right)$, PG supplied large amounts of $\mathrm{Ca}$ which were found to decrease $\mathrm{Al}$ activity in soil solution when $\mathrm{Ca}^{2+} / \mathrm{Al}^{3+}$ ratio is high even if exchangeable $\mathrm{Al}$ is high [31], therefore alleviating its deleterious effects on roots [32,33].

The fact that P uptakes were not significantly affected by P supply for PG and PS treatments in the absence of lime compared with the control (R0), gives insight that this was likely related to other factors, probably soil $\mathrm{pH}$. This explanation is strongly supported by higher $\mathrm{P}$ uptakes measured under 
Lime + PG and Lime + PS where $\mathrm{pH}$ is significantly higher. Similar findings were recently found by Otieno et al. [34] in acid soils of western Kenya. Additionally, the combination PG + L has been reported to stimulate soil microbial activity $[35,36]$ and this could have improved phosphorus bioavailability.

The continuous increase in shoot uptaken S per pot with PG and PS rate increase indicates that lucerne was still S-uptake responsive to $S$ supply even at high rates and that PG can be an alternative source for $\mathrm{S}$ fertilization as it performed almost identically to soluble fertilizer in both soils. The sulphur concentration of shoots under different PG and PS rates exceeded the optimum range of $0.18-0.22 \% \mathrm{~S}$, suggested by Craighead and Metherell [37] for NZ high and hill country farms.

Lime addition increased S uptake under both PG and PS treatments. This was likely due to the mobilization of the adsorbed $\mathrm{SO}_{4}{ }^{2-}$ at low $\mathrm{pHs}[38,39]$. The effect of lime is usually attributed to the competition between $\mathrm{OH}^{-}$and $\mathrm{SO}_{4}{ }^{2-}$ on adsorption sites on $\mathrm{Fe}$ and $\mathrm{Al}$ hydrous oxides and $\mathrm{P}$ compounds may also compete for adsorption sites as they become more soluble at higher $\mathrm{pHs}$ [40]. Furthermore, the enhancement of root growth following lime application could also explain the greater uptakes of $\mathrm{P}$ and $\mathrm{S}$ with increased soil $\mathrm{pH}$ (Figure $\mathrm{S} 1$ ).

We can conclude from the negative linear relationships exhibited between shoot dry matter yields and the shoot concentration of $\mathrm{P}$ and $\mathrm{S}$ (Table 7), that $\mathrm{P}$ and $\mathrm{S}$ supply may not be limiting the yield in GM soil. This explanation is supported by the observed mean nutrient concentrations in the plant shoots, which are in "adequate" range according to Craighead and Metherell; Morton et al.; Venter et al. [37,41,42]. This hypothesis is also in line with the TDM yield data in GM soil where no significant differences were found between the control and treated soils with $\mathrm{P}$ and $\mathrm{S}$ either through PS or PG, except PG (R3 + Lime). Conversely, the decrease of P and S content of shoots with increased yield could be due to the " dilution effect" associated with the extra dry matter production [43].

Table 7. Correlation matrices of the nutrient concentrations ( $\mathrm{g} \mathrm{kg}^{-1}$ of shoot DM) and shoot DM yield (g) produced in GM and MO soils.

\begin{tabular}{lcccc}
\hline & \multicolumn{2}{c}{ Glenmore (GM) Soil } & \multicolumn{2}{c}{ Molesworth (MO) Soil } \\
\hline & Shoot DM & S Content & Shoot DM & S Content \\
\hline S content & $-0.65^{* * *}$ & & -0.19 n.s. & \\
P content & $-0.53^{* * *}$ & $-0.40^{* *}$ & -0.11 n.s. & $0.41^{*}$ \\
\hline
\end{tabular}

Asterisks indicate significance levels of the relations $\left({ }^{*} p<0.05,{ }^{* *} p<0.01,{ }^{* * *} p<0.001\right)$, n.s. not significant.

The correlation matrix showed weak relationships between nutrients concentrations and shoot yield under MO soil. However, the mean P concentrations across all treatments were below deficiency values. This indicates that the uptake of $\mathrm{P}$ is not solely dependent on its availability in this soil but influenced by other factors, most likely soil $\mathrm{pH}$. Although no strong correlation was found between shoot yield and shoot $\mathrm{S}$ concentrations, an increase in $\mathrm{S}$ concentration was recorded when sulphur was supplied through PG and PS compared to the control. This could be explained by the luxury consumption of $S$ by lucerne [42], which means that not all the $S$ removed by the crop is essential for plant growth.

\subsection{Phosphogypsum Effects on Soil pH, Olsen P and Exchangeable Aluminum}

The lower soil $\mathrm{pH}\left(\mathrm{H}_{2} \mathrm{O}\right)$ resulting from phosphogypsum addition was consistent with the findings of Nayak et al.; Lee et al.; Jarak et al. [24,35,44]. The PG used in this study had a high calcium content which likely displaced $\mathrm{Al}^{3+}$ and $\mathrm{H}^{+}$on cation exchange sites into the soil solution resulting in low $\mathrm{pH}$, this view is supported by the measured $\mathrm{pH}\left(\mathrm{H}_{2} \mathrm{O}\right)$ under PS treatments, where Ca supply was largely lower compared to $\mathrm{PG}$, which resulted in a relatively stable $\mathrm{pH}\left(\mathrm{H}_{2} \mathrm{O}\right)$. Besides, the low $\mathrm{pH}\left(\mathrm{H}_{2} \mathrm{O}, 3.5\right)$ of this PG product likely contributed to acidifying the soil. On the other hand, Smith et al. [45] found that the $\mathrm{pH}$ of surface amended soil with $2.5 \mathrm{tha}^{-1}$ of $\mathrm{PG}$ was unchanged.

The $\mathrm{pH}\left(\mathrm{CaCl}_{2}\right)$ results in this study showed an opposite trend to $\mathrm{pH}\left(\mathrm{H}_{2} \mathrm{O}\right)$, especially for unlimed $\mathrm{MO}$ soil as its $\mathrm{pH}\left(\mathrm{CaCl}_{2}\right)$ increased slightly with PG. This confirmed what was reported recently 
about the increase of soil $\mathrm{pH}$ at depths of 0 to $5 \mathrm{~cm}$ by Crusciol et al. [27], after the surface application of phosphogypsum. Further, this result corroborates early reports by Toma et al. [4], who found that gypsum application decreased $\mathrm{pH}\left(\mathrm{H}_{2} \mathrm{O}\right)$ while $\mathrm{pH}\left(\mathrm{CaCl}_{2}\right)$ did not. This could be explained by $\mathrm{pH}\left(\mathrm{H}_{2} \mathrm{O}\right)$ overshadowing the liming effect of phosphogypsum due to the salt effect, whereas measuring $\mathrm{pH}$ in $0.01 \mathrm{M} \mathrm{CaCl}_{2}$ kept constant the effect of salt on the hydrolysis of $\mathrm{Al}$ forms releasing $\mathrm{H}^{+}$protons. Moreover, in a pot experiment conducted by Edmeades et al. [7] where they recorded the same behavior between $\mathrm{pH}(\mathrm{KCl})$ and $\mathrm{pH}\left(\mathrm{H}_{2} \mathrm{O}\right)$, this was claimed to be related to the decrease of ionic strength of the solution after dilution with $\mathrm{H}_{2} \mathrm{O}$. Therefore, in glasshouse studies where soil volume is limited promoting high ionic strength conditions, the interpretation of $\mathrm{pH}\left(\mathrm{H}_{2} \mathrm{O}\right)$ must be done carefully. Similarly, $\mathrm{CaCl}_{2}$ extracted $\mathrm{pH}$ increased significantly under PS for unlimed $\mathrm{MO}$ and limed GM. The observed rise in $\mathrm{pH}\left(\mathrm{CaCl}_{2}\right)$ following PS and PG application to the soil can also be ascribed to ligand exchange, whereby the supplied $\mathrm{SO}_{4}{ }^{2-}$ replaces $\mathrm{OH}^{-}[46,47]$. So, considering these factors, we can state that the PG and PS effect on soil pH likely depends on the balance between $\mathrm{Ca}^{2+}$ and $\mathrm{SO}_{4}{ }^{2-}$ reactions.

The observed reduction in soil $\mathrm{Al}$ concentrations under soils treated with $1 \mathrm{t} \mathrm{ha}^{-1}$ of PG agrees with Crusciol et al. [27]. This effect can be explained by the association of the $\mathrm{Al}^{3+}$ ions with $\mathrm{SO}_{4}{ }^{2-}$ and $\mathrm{F}^{-}$forming ionic pairs $\mathrm{AlSO}^{4+}, \mathrm{AlF}_{2}{ }^{+}, \mathrm{AlF}^{2+}$ and $\mathrm{AlF}_{3}{ }^{0}$ [48]. The absence of $\mathrm{PG}$ restriction effects on exchangeable $\mathrm{Al}$ at $9 \mathrm{t} \mathrm{ha}^{-1}$ for both $\mathrm{MO}$ and GM soils was probably due to the higher ionic strength in the soil solution. This would favor ionic exchange reactions to the detriment of adsorption and precipitation reactions. Hence, the ionic exchange of $\mathrm{Ca}^{2+}$ would have increased $\mathrm{Al}^{3+}$ in the solution and dominated the ligand exchange reactions. Additionally, at $\mathrm{PG}\left(9 \mathrm{tha}^{-1}\right)$ the $\mathrm{pH}\left(\mathrm{H}_{2} \mathrm{O}\right)$ has dropped by 0.4 and 0.34 units compared to the control in unlimed GM and MO soils respectively. This triggered an increase of exchangeable $\mathrm{Al}$ in GM and MO soils. This inverse relationship between $\mathrm{pH}$ and exchangeable $\mathrm{Al}$ in New Zealand soils has been confirmed by several researchers [8,49-55]. However, the observed increase in exchangeable $\mathrm{Al}$ under PS treatments was not related to soil $\mathrm{pH}$ which was unchanged. This agrees with the findings of Horsnell [56], in a glasshouse experiment, where those workers found that neutral salts $\left(\mathrm{K}_{2} \mathrm{SO}_{4}\right.$ or $\left.\mathrm{CaSO}_{4}\right)$ in the presence of calcium phosphate increased aluminum concentrations in soil solution.

The difference between the influence of PG $\left(R 1=1 \mathrm{tha}^{-1}\right)$ and PG $\left(\mathrm{R} 3=9 \mathrm{tha}^{-1}\right)$ in the absence of lime on Olsen P was larger (6 units) for MO soil, while under GM soil it was small (only 1 unit). This has probably resulted from a sharp decrease in GM soil $\mathrm{pH}$ when $9 \mathrm{t} \mathrm{ha}^{-1}$ of PG was applied, which would have consequently increased $P$ adsorption [57] on oxide surfaces. This explanation is also supported by the high exchangeable $\mathrm{Al}$ content measured in unlimed GM under PG $\left(9 \mathrm{tha}^{-1}\right)$, which exceeded that of PG $\left(1 \mathrm{t} \mathrm{ha}^{-1}\right)$ by $14.6 \mathrm{mg} \mathrm{kg}^{-1}$ of soil.

The effect of PG on soil P availability is comparatively similar to that of soluble fertilizer used in this study as a standard source of $\mathrm{P}$ and $\mathrm{S}$. This indicates the high solubility of total P contained in PG materials and its ability to be easily released into the soil and therefore be available to the plants in the same manner as soluble fertilizers. Phosphogypsum amendment could also have improved the microbial activity and population in the soil $[24,35,36,58]$ resulting in a higher P solubility.

Lime application decreased Olsen $P$ for both soils regardless of treatment type. Our results are in line with studies done by other workers on acid soils $[59,60]$. This decline in soil $\mathrm{P}$ under lime application can be due to the formation of Ca-P precipitates [61]. Moreover, when $\mathrm{pH}$ is increased, the proportion of absorbable $\mathrm{P}$ species increases such as the divalent phosphate $\left(\mathrm{HPO}_{4}{ }^{2-}\right)$ [62] . The formation of insoluble hydroxyl-Al species following lime can also be highly active adsorption surfaces for phosphate [63]. Haynes and Ludecke [64] reported an increase in Al-bound P fraction under liming. Moreover, the stability of hydroxyl-Al-P complexes has been reported to be high around $\mathrm{pH} 5$ [65]. However, the decrease in P availability following liming is not supported by plant shoot $\mathrm{P}$ uptake in this experiment, which showed a significant increase when lime was applied. Alternative soil $\mathrm{P}$ tests under liming conditions are recommended as the decline of Olsen $\mathrm{P}$ could be due to an artifact in the Olsen procedure which uses high $\mathrm{pH}$ extractant $(\mathrm{pH} 8)$ favoring the Ca-P precipitation [60]. 


\section{Materials and Methods}

\subsection{Soil Characteristics}

Two acid soils with different chemical and physical properties were used (Table 8). They were collected from two different sites and are known to be phosphorus-deficient and have high bioavailable Al concentrations. The "GM" soil was sampled from Glenmore station, located on the southern banks of Lake Tekapo, central Canterbury, while the "MO" soil was collected from Molesworth station, in the Marlborough region. The two soils are classified as Dystrudepts [66] or Brown soils (NZ soil classification after [67]). Upon collection $(0-15 \mathrm{~cm})$, plant material and stones were removed. The soils were air-dried and sieved ( $4 \mathrm{~mm}$ mesh).

Table 8. Results of soil chemical and particle-size distribution before the establishment of the experiment.

\begin{tabular}{|c|c|c|c|}
\hline Soil Analysis & Molesworth & Glenmore & By Method of \\
\hline $\mathrm{pH}\left(\mathrm{H}_{2} \mathrm{O}\right)$ & 4.7 & 5.0 & [68] \\
\hline Olsen $\mathrm{P}(\mu \mathrm{g} / \mathrm{mL})$ & 13 & 18 & [69] \\
\hline Resin $\mathrm{P}(\mathrm{mg} / \mathrm{kg})$ & 24 & 31 & [70] \\
\hline $\mathrm{P}$ retention $(\%)$ & 59 & 42 & [68] \\
\hline Inorganic $\mathrm{P}(\mathrm{mg} / \mathrm{kg})$ & 160 & 196 & \\
\hline Organic P (mg/kg) & 440 & 696 & [71-73] \\
\hline $\mathrm{P}$ organic/P inorganic ratio & 2.75 & 3.55 & \\
\hline Sulphate sulphur ( $\mu \mathrm{g} / \mathrm{g})$ & 9 & 15 & [74] \\
\hline Reserve K (me/100 g) & 6.45 & 2.10 & [75] \\
\hline Anaerobic Min N (kg/ha) & 102 & 169 & [76] \\
\hline Organic matter (\% w/w) & 8.5 & 10.6 & [68] \\
\hline Exchangeable $\mathrm{Al}(\mathrm{mg} / \mathrm{kg})$ & 21 & 8 & [77] \\
\hline Total $\mathrm{N}(\% \mathrm{w} / \mathrm{w})$ & 0.38 & 0.53 & (Dumas combustion method usino an \\
\hline Total C (\% w/w) & 4.91 & 6.18 & (Dumas combustion method using an \\
\hline Carbon/Nitrogen & 12.9 & 11.7 & Elementar Varıo Max Cube Analyzer) \\
\hline CEC (meq/100 g) & 14 & 17 & [78] \\
\hline $\mathrm{Ca}(\mathrm{meq} / 100 \mathrm{~g})$ & 0.9 & 4.7 & \\
\hline $\mathrm{Mg}(\mathrm{meq} / 100 \mathrm{~g})$ & 0.43 & 0.79 & \\
\hline $\mathrm{K}(\mathrm{meq} / 100 \mathrm{~g})$ & 0.40 & 0.36 & [79] \\
\hline $\mathrm{Na}(\mathrm{meq} / 100 \mathrm{~g})$ & 0.06 & 0.07 & \\
\hline Base saturation $(\%)$ & 12.9 & 34.1 & \\
\hline Particle-Size distribution $\%$ & & & ISSS Classification \\
\hline Clay $(0.05-2 \mu \mathrm{m})$ & 17 & 13 & \\
\hline Sand $(20-2000 \mu \mathrm{m})$ & 51 & 48 & \\
\hline Silt $(2-20 \mu \mathrm{m})$ & 32 & 40 & \\
\hline
\end{tabular}

ISSS International Society of Soil Science.

\subsection{Experimental Design and Treatments}

The sieved soils were subjected to one of four treatments. In PG treatment, four rates of phosphogypsum: 0, 1, 3 and $9 \mathrm{t} \mathrm{ha}^{-1}\left(5.4,16.2\right.$ and $48.6 \mathrm{~kg} \mathrm{P} \mathrm{ha}^{-1}$ and, 113, 339 and $1017 \mathrm{~kg} \mathrm{of} \mathrm{S} \mathrm{ha}^{-1}$ respectively) were applied. In the soluble fertilizer (PS) treatment, $\mathrm{P}$ and $\mathrm{S}$ were applied at four rates to match the amount of the nutrients in the PG treatment: P was supplied as 0, 22, 66 and $198 \mathrm{~kg}$ of monocalcium phosphate $\left(\mathrm{CaHPO}_{4}\right) \mathrm{ha}^{-1}$, while $\mathrm{S}$ was supplied as $0,0.5,1.5$ and $4.5 \mathrm{tha}^{-1}$ of Sodium sulphate $\left(\mathrm{Na}_{2} \mathrm{SO}_{4}\right)$. The rates of PG and PS were gradually increased to achieve an optimum Olsen P range of $25-30 \mathrm{mg} \mathrm{kg}^{-1}$ for lucerne $[80,81]$ at the highest rate. The chemical composition of PG and soluble fertilizers used in this study is presented in Table 9. 
Table 9. Chemical composition of the fertilizers used in the experiment.

\begin{tabular}{cccccccccccc}
\hline & & $\mathrm{pH}_{\mathbf{w}}$ & $\mathbf{P}$ & $\mathbf{K}$ & $\mathbf{S}$ & $\mathbf{C a}$ & $\mathbf{M g}$ & $\mathbf{N a}$ & $\mathbf{A l}$ & $\mathbf{A s}$ & $\mathbf{C d}$ \\
\hline $\begin{array}{c}\text { Phosphogypsum } \\
\text { Monocalcium } \\
\text { phosphate }\end{array}$ & $\%(\mathrm{wt} / \mathrm{wt})$ & 3.5 & 0.54 & 0.08 & 11.30 & 16.11 & 0.03 & 0.19 & 0.12 & $4.10^{-4}$ & $2.10^{-4}$ \\
$\begin{array}{c}\text { Sodium sulphate } \\
\text { (wt/wt) }\end{array}$ & - & 24.6 & - & 0.1 & 15.9 & - & - & - & - & - \\
\hline
\end{tabular}

$\mathrm{wt} / \mathrm{wt}=$ weight $/$ weight.

The four rates of PG and PS are reported in the text, tables and figures as R0, R1, R2 and R3 respectively and each rate supplies the same amount of P and S for both PG and PS. The control treatment corresponds to rate 0 (R0) where no $\mathrm{P}$ and $\mathrm{S}$ inputs were supplied.

Both PG and soluble fertilizer (PS) treatments were applied alone (without lime: $0 \mathrm{t} \mathrm{ha}^{-1}$ ) but were also applied in combination with lime $\left(2 \mathrm{tCaCO}_{3} \mathrm{ha}^{-1}\right.$, lab-grade lime). This experiment was a $4 \times 2 \times 2$ factorial design with 4 rates of PG or PS separately, two soils and two lime rates $\left(0\right.$ and $\left.2 \mathrm{tha}^{-1}\right)$. Four replicates were used for each treatment level, giving a total of 112 pots. The lime treatment was included to increase soil $\mathrm{pH}$ and thus facilitate seedling emergence and plant establishment and to test for possible interactions with PG and PS. The lime rate of $2 \mathrm{tha}^{-1}$ has been used based on the findings of a pot experiment [82]. It has been reported to be an optimum lime rate for lucerne yielding under the same soil types investigated in this study.

Lime, PG and soluble fertilizer treatments were thoroughly mixed with $200 \mathrm{~g}$ of air-dried soil. Basal potassium (K) was also mixed with the soil ( $300 \mathrm{~kg}$ of $\mathrm{K} \mathrm{ha}^{-1}$ as $\left.\mathrm{KCl}\right)$. The treated soils were deployed in $250 \mathrm{~mL}$ plastic plant pots $(66 \mathrm{~mm}$ diameter $\times 75 \mathrm{~mm}$ height) and distributed in a complete randomized block design on a table at Lincoln University (Lincoln, NZ) glasshouse facilities. The daily average temperature for the experiment period was $18{ }^{\circ} \mathrm{C}$. A small pot size was used to create a rhizosphere environment where nutrient uptake could be enhanced and to speed up soil nutrient cycling enabling to see treatment effect in short period of time. However, this could negatively impact plant growth.

Lucerne ( $M$. sativa, cv. Grasslands Kaituna) seeds were directly sown into the pots. After germination, the plants in each pot were thinned to 3 seedlings per pot and grown for six months, between March 16th to September 23rd, 2018. The pots were inoculated with a commercial (diluted peat culture) rhizobia strain, Group AL (New-Edge Microbials Pty. Ltd., Albury, Australia) 30 days post-germination to insure that an active rhizobia population is present in the soil. Throughout the growth period, soil moisture was monitored using high-frequency capacitance volumetric water content sensors (Decagon 5TM, Decagon Devices LTD, Pullman, Washington, USA) installed within the soil and maintained at $22-25 \%(\mathrm{v} / \mathrm{v})$ by an automated dripper irrigation system.

\subsection{Plant and Soil Sampling and Analysis}

Lucerne shoots were harvested four times during the experiment period by cutting $2 \mathrm{~cm}$ above the crown of each plant, oven-dried at $70{ }^{\circ} \mathrm{C}$ for $48 \mathrm{~h}$, weighed, finely ground and bulked on an individual pot basis. Therefore, shoot nutrient uptake data shown in this study represents the average of the four harvests and shoot DM yields data represents the sum of the four harvests per pot. At the end of the experiment, the roots were harvested, whereupon they were carefully cleaned using deionized water, dried at $70{ }^{\circ} \mathrm{C}$ for $48 \mathrm{~h}$ and then weighed. The soils were then collected and air-dried at $30^{\circ} \mathrm{C}$ for 7 days. After drying the soil was sieved $(2 \mathrm{~mm})$ and stored at room temperature in polyethylene bags to await for analysis.

The chemical characteristics of the soils were determined using standard methods (Table 8). Soil pH (1:2.5 soil: water ratio) was measured using both deionized water and $0.01 \mathrm{M} \mathrm{CaCl}_{2}$. Bioavailable soil P (Olsen $\mathrm{P}$ ) was extracted using $0.5 \mathrm{M}$ sodium bicarbonate and was analyzed in a discrete wet chemistry analyzer (Smartchem TM 200, AMS Alliance, Paris, France). Exchangeable aluminum was extracted using $0.02 \mathrm{M} \mathrm{CaCl}_{2}$ (1:4 soil: water ratio) and analyzed using Inductively Coupled Plasma Optical Emission Spectrophotometry (ICP-OES: Varian 720-ES ICP-OES, Varian, Melbourne, Australia). 
Herbage samples underwent acid digestion (Nitric acid $\left(\mathrm{HNO}_{3} 69 \%\right)$-Hydrogen Peroxide $\left.\left(\mathrm{H}_{2} \mathrm{O}_{2} 30 \%\right), 1: 1 \mathrm{v} / \mathrm{v}\right)$ using a microwave digester (CEM MARS XpressTM, CEM Corp., Matthews, North Carolina, USA) [83]. The digest solution was analyzed for total P and S using Inductively Coupled Plasma Optical Emission Spectrophotometer (ICP-OES: Varian 720-ES ICP-OES, Varian, Melbourne, Australia).

\subsection{Statistical Analysis}

The data were analyzed at the end of the experiment and were subjected to analysis of variance (ANOVA) using Minitab ${ }^{\circledR}$ statistical software version 8 (Minitab, Inc., State College, Pennsylvania, USA). The phosphogypsum or soluble fertilizer treatments, lime treatments and soil types were considered as fixed factors. Three-way ANOVA was carried out to test the significance of the main effect of each factor and to identify any significant interactions between them, it was carried out for (PG, lime and soil types) and (PS, lime and soil types) separately. One-way-ANOVA was used to test the effect of treatment levels on soil parameters (Olsen $\mathrm{P}, \mathrm{pH}$ and exchangeable $\mathrm{Al}$ ) and plant parameters (yield and uptakes). Where differences between the means were significant $(p<0.05)$, the Dunnett test $(\alpha=5 \%)$ was used to compare treatment levels to the control level. The comparison between PS and PG effect per rate on TDM yield was performed using a two-sample $t$-test at $5 \%$. The effects were considered to be significant when $p \leq 0.05$. A correlation matrix was developed using the Pearson method to establish the relationships between $\mathrm{P}$ and $\mathrm{S}$ concentrations in the shoots and shoot DM yields. A simple linear regression was used to study the relationship between PG and PS application rates and soil Olsen P. A multiple linear regression (backward elimination) was used to determine the most important soil variable ( $\mathrm{pH}$, Olsen $\mathrm{P}$ or exchangeable $\mathrm{Al})$ in impacting TDM yield. The variables were standardized by subtracting the mean then divide by standard deviation.

\section{Conclusions}

Phosphogypsum application on acid soils showed positive effects on soil P availability, P and S uptakes and consequently on lucerne biomass production. However, the effects of PG on soil acidity depends on soil properties. Its magnitude of $\mathrm{pH}$-neutralizing effects does not support PG to be used as a lime substitute but rather as a fertilizer supplement. The responses to PG would not be maximized without being necessarily combined with a $\mathrm{pH}$ ameliorant such as lime in our case. The strategy of blending materials might be feasible for acid soils and can be a real solution for the improvement of lime solubility and therefore its reaction time and movement down to the sub-soil layers. However, there is a lack of evidence about it, hence further studies are required in this aspect. Phosphogypsum has decreased exchangeable $\mathrm{Al}$ at low rates, this warrants further investigations are necessary to evaluate the effects of PG on Al species. Further studies are also required to identify Al toxicity thresholds for legumes. The $\mathrm{Ca}$ effect on $\mathrm{Al}$ activity and phytotoxicity could also support the use of Ca-rich materials such as PG on acid soils.

The sustainable utilization of PG in agriculture necessitates long-term experiments focusing not only on fertilizing effects of PG but paralleled with an environmental impact assessment. Also, the assessment of PG effects on nutritional imbalances especially at high application rates is needed.

Soluble fertilizer used in this study $\left(\mathrm{MCP}+\mathrm{NaSO}_{4}\right)$, if used without lime, may not be the most effective for the establishment and growth of lucerne on acid soils with high native exchangeable aluminum levels. The increased $\mathrm{Al}$ concentrations following the combination of $\mathrm{MCP}$ and $\mathrm{NaSO}_{4}$ requires further investigation.

Supplementary Materials: The following are available online at http://www.mdpi.com/2223-7747/9/7/883/s1, Figure S1: Lime addition effect on overall average root dry matter (DM) accumulated under each soil (MO and GM indicate Molesworth and Glenmore soils, respectively). Error bars are standard errors $( \pm \mathrm{SE}, \mathrm{n}=28)$, Asterisks indicate the significance of two-sample $t$-test at $5 \%$ for liming $\left(2 \mathrm{t} \mathrm{ha}^{-1}\right)$ effect compared to no lime conditions $\left(0 \mathrm{t} \mathrm{ha}^{-1}\right)\left({ }^{*} p<0.05,{ }^{* *} p<0.01,{ }^{* * *} p<0.001\right)$. 
Author Contributions: M.B., J.M., L.C., and N.L., contributed to the study conception and design; M.B. and J.M. performed the experiment; M.B. analyzed the data; The first draft of the manuscript was written by M.B. and all authors commented on previous versions of the manuscript. All authors have read and agreed to the published version of the manuscript.

Funding: This project was funded by Mohammed VI Polytechnic University (UM6P, Morocco) and Office Chérifien des Phosphates (OCP, Morocco) under a collaborative research program with Lincoln University.

Acknowledgments: We thank Lincoln University technical staff, in particular: Roger Cresswell, Lynne Clucas, Dharini Paramashivam and Leanne Hassall for laboratory assistance, Neil Smith for assistance with the irrigation system and Brent Richards for glasshouse facilities.

Conflicts of Interest: The authors declare no conflict of interest.

\section{References}

1. Haynes, R.; Williams, P. Nutrient cycling and soil fertility in the grazed pasture ecosystem. Adv. Agron. 1993, 49, 119-199.

2. Maxwell, T.; Moir, J.; Edwards, G. Phosphorus response and efficiency of four adventive annual clovers grown in a New Zealand high country soil under glasshouse conditions. N. Z. J. Agric. Res. 2013, 56, $203-214$. [CrossRef]

3. Moir, J.; Jordan, P.; Moot, D.; Lucas, R. Phosphorus response and optimum pH ranges of twelve pasture legumes grown in an acid upland New Zealand soil under glasshouse conditions. J. Soil Sci. Plant Nutr. 2016, 16, 438-460. [CrossRef]

4. Toma, M.; Sumner, M.; Weeks, G.; Saigusa, M. Long-term effects of gypsum on crop yield and subsoil chemical properties. Soil Sci. Soc. Am. J. 1999, 63, 891-895. [CrossRef]

5. Rechcigl, J.; Edmisten, K.; Wolf, D.; Reneau, R. Response of alfalfa grown on acid soil to different chemical amendments. Agron. J. 1988, 80, 515-518. [CrossRef]

6. Su, C.; Evans, L. Soil solution chemistry and alfalfa response to $\mathrm{CaCO}_{3}$ and $\mathrm{MgCO}_{3}$ on an acidic gleysol. Can. J. Soil Sci. 1996, 76, 41-47. [CrossRef]

7. Edmeades, D.; Smart, C.; Wheeler, D. Aluminium toxicity in New Zealand soils: Preliminary results on the development of diagnostic criteria. N. Z. J. Agric. Res. 1983, 26, 493-501. [CrossRef]

8. Moir, J.L.; Moot, D.J. Soil pH, exchangeable aluminium and lucerne yield responses to lime in a South Island high country soil. In Proceedings of the New Zealand Grassland Association Conference, Lincoln, New Zealand, 14-18 November 2010; pp. 191-196.

9. Kirchhof, G.; Jayawardane, N.; Blackwell, J.; Murray, E. Lime-slotting technique to ameliorate subsoil acidity in a clay soil. 1. Effects on soil-pH and physical characteristics. Soil Res. 1995, 33, 425-441. [CrossRef]

10. Hendrie, D.L.; Moir, J.L.; Stevens, E.J.; Black, A.D.; Moot, D.J. Soil pH, exchangeable aluminium and legume yield responses to deep-placed lime at Omarama Station. J. N. Z. Grassl. 2018, 80, 137-144. [CrossRef]

11. Moir, J.; Scotter, D.; Hedley, M.; Mackay, A. A climate-driven, soil fertility dependent, pasture production model. N. Z. J. Agric. Res. 2000, 43, 491-500. [CrossRef]

12. Gillingham, A.; Maber, J.; Morton, J.; Tuohy, M. Precise aerial fertiliser application on hill country. In Proceedings of the New Zealand Grassland Association Conference, Hawkes Bay, New Zealand, 1999; pp. 221-226.

13. IAEA. Radiation Protection and Management of NORM Residues in the Phosphate Industry; International Atomic Energy Agency: Vienna, Austria, 2013.

14. Saadaoui, E.; Ghazel, N.; Ben Romdhane, C.; Massoudi, N. Phosphogypsum: Potential uses and problems-A review. Int. J. Environ. Stud. 2017, 74, 558-567. [CrossRef]

15. Arnold, W.; Hurst, F. Uranium Control in Phosphogypsum. In Proceedings of the International Symposium on Phosphogypsum, Lake Buena Vista, FL, USA, 5-7 November 1980; pp. 367-382.

16. Mazzilli, B.; Palmiro, V.; Saueia, C.; Nisti, M. Radiochemical characterization of Brazilian phosphogypsum. J. Environ. Radioact. 2000, 49, 113-122. [CrossRef]

17. Rutherford, P.; Dudas, M.; Arocena, J. Radium in phosphogypsum leachates. J. Environ. Qual. 1995, 24, 307-314. [CrossRef]

18. Alcordo, I.S.; Rechcigl, J.E. Phosphogypsum in agriculture: A review. Adv. Agron. 1993, 49, 55-118. 
19. Abril, J.-M.; García-Tenorio, R.; Enamorado, S.M.; Hurtado, M.D.; Andreu, L.; Delgado, A. The cumulative effect of three decades of phosphogypsum amendments in reclaimed marsh soils from SW Spain: 226Ra, 238U and Cd contents in soils and tomato fruit. Sci. Total Environ. 2008, 403, 80-88. [CrossRef]

20. Vyshpolsky, F.; Qadir, M.; Karimov, A.; Mukhamedjanov, K.; Bekbaev, U.; Paroda, R.; Aw-Hassan, A.; Karajeh, F. Enhancing the productivity of high-magnesium soil and water resources in Central Asia through the application of phosphogypsum. Land Degrad. Dev. 2008, 19, 45-56. [CrossRef]

21. Mesić, M.; Brezinščak, L.; Zgorelec, Ž.; Perčin, A.; Šestak, I.; Bilandžija, D.; Trdenić, M.; Lisac, H. The application of phosphogypsum in agriculture. Agric. Conspec. Sci. 2016, 81, 7-13.

22. Armstrong, A.; Tanton, T. Gypsum applications to aggregated saline-Sodic clay topsoils. J. Soil Sci. 1992, 43, 249-260. [CrossRef]

23. AĞAR, A.İ. Reclamation of saline and sodic soil by using divided doses of phosphogypsum in cultivated condition. Afr. J. Agric. Res. 2011, 6, 4243-4252. [CrossRef]

24. Nayak, S.; Mishra, C.; Guru, B.; Rath, M. Effect of phosphogypsum amendment on soil physico-chemical properties, microbial load and enzyme activities. J. Environ. Biol. 2011, 32, 613.

25. Degirmenci, N.; Okucu, A.; Turabi, A. Application of phosphogypsum in soil stabilization. Build. Environ. 2007, 42, 3393-3398. [CrossRef]

26. Masud, M.; Li, J.-Y.; Xu, R.-K. Application of alkaline slag and phosphogypsum for alleviating soil acidity in an Ultisol profile: A short-term leaching experiment. J. Soils Sediments 2015, 15, 365-373. [CrossRef]

27. Crusciol, C.A.; Artigiani, A.C.; Arf, O.; Carmeis Filho, A.C.; Soratto, R.P.; Nascente, A.S.; Alvarez, R.C. Surface application of lime-silicate-phosphogypsum mixtures for improving tropical soil properties and irrigated common bean yield. Soil Sci. Soc. Am. J. 2016, 80, 930-942. [CrossRef]

28. Caires, E.F.; Guimarães, A.M. A Novel Phosphogypsum Application Recommendation Method under Continuous No-Till Management in Brazil. Agron. J. 2018, 110, 1987-1995. [CrossRef]

29. Moir, J.; Hedley, M.; Mackay, A.; Tillman, R. The effect of fertiliser history on nutrient accumulation and plant-available nutrient supply in legume-based pasture soils. In Proceedings of the XVII International Grassland Congress, Winnipeg, MB, Canada, 1997; pp. 68-69.

30. Morton, J.; Roberts, A. Fertiliser Use on New Zealand Sheep and BeefFarms; New Zealand Fertiliser Manufacturers' Research Association: Auckland, New Zealand, 1999.

31. Cunha, G.O.d.M.; Almeida, J.A.d.; Ernani, P.R.; Pereira, É.R.; Skoronski, É.; Lourenço, L.S.; Brunetto, G. Chemical species and aluminum concentration in the solution of acid soils cultivated with soybean and corn under liming. Rev. Bras. Ciênc. Solo 2018, 42. [CrossRef]

32. Rengel, Z. Role of calcium in aluminium toxicity. New Phytol. 1992, 121, 499-513. [CrossRef]

33. Brady, D.; Edwards, D.; Asher, C.; Blamey, F. Calcium amelioration of aluminium toxicity effects on root hair development in soybean [Glycine max (L.) Merr.]. New Phytol. 1993, 123, 531-538. [CrossRef]

34. Otieno, H.M.; Chemining'Wa, G.N.; Zingore, S. Effect of farmyard manure, lime and inorganic fertilizer applications on soil $\mathrm{pH}$, nutrients uptake, growth and nodulation of soybean in acid soils of western Kenya. J. Agric. Sci. 2018, 10, 199-208. [CrossRef]

35. Lee, C.H.; Ha, B.Y.; Lee, Y.B.; Kim, P.J. Effect of alkalized phosphogypsum on soil chemical and biological properties. Commun. Soil Sci. Plant Anal. 2009, 40, 2072-2086. [CrossRef]

36. Inagaki, T.M.; de Moraes Sá, J.C.; Caires, E.F.; Gonçalves, D.R.P. Lime and gypsum application increases biological activity, carbon pools, and agronomic productivity in highly weathered soil. Agric. Ecosyst. Environ. 2016, 231, 156-165. [CrossRef]

37. Craighead, M.; Metherell, A. The impact of the form and frequency of sulphur on pasture yield and composition in South Island high country. In Proceedings of the New Zealand Grassland Association Conference, Dunedin, New Zealand, 2006; pp. 361-367.

38. Martini, J.; Mutters, R. Effect of liming and fertilization on sulfur availability, mobility, and uptake in cultivated soils of south carolina1. Soil Sci. 1984, 138, 403-410. [CrossRef]

39. Mehlich, A. Influence of Sorbed Hydroxyl and Sulfate on Liming Efficiency, pH, and Conductivity 1. Soil Sci. Soc. Am. J. 1964, 28, 496-499. [CrossRef]

40. Korentajer, L.; Byrnes, B.H.; Hellums, D.T. The Effect of Liming and Leaching on the Sulfur-Supplying Capacity of Soils 1. Soil Sci. Soc. Am. J. 1983, 47, 525-530. [CrossRef] 
41. Morton, J.D.; Grace, N.D.; O'Connor, M.B. Use of Trace Elements in New Zealand Pastoral Farming: The Principles and Practice of Meeting Trace Element Requirements of Pastures and Animals; New Zealand Fertiliser Manufacturers' Research Association: Aukland, New Zealand, 1999.

42. Venter, A.; Beukes, D.; Claassens, A.; Van Meirvenne, M. Temporal and spatial relations of plant element uptake and yield of a lucerne stand. S. Afr. J. Plant Soil 2004, 21, 157-165. [CrossRef]

43. Jarrell, W.; Beverly, R. The dilution effect in plant nutrition studies. Adv. Agron. 1981, 34, 197-224.

44. Jarak, M.; Belic, M.; Govedarica, M.; Milosevic, N.; Djuric, S. Effect of phosphogypsum and peat on microbiological and chemical properties of arenosol. Acta Biol. Iugosl. Ser. A 2004, 52, 1-6.

45. Smith, C.; Peoples, M.; Keerthisinghe, G.; James, T.; Garden, D.; Tuomi, S. Effect of surface applications of lime, gypsum and phosphogypsum on the alleviating of surface and subsurface acidity in a soil under pasture. Soil Res. 1994, 32, 995-1008. [CrossRef]

46. Hue, N.; Adams, F.; Evans, C. Sulfate Retention by an Acid BE Horizon of an Ultisol. Soil Sci. Soc. Am. J. 1985, 49, 1196-1200. [CrossRef]

47. Turner, L.; Kramer, J. Sulfate ion binding on goethite and hematite. Soil Sci. 1991, 152, 226-230. [CrossRef]

48. Carvalho, M.; Van Raij, B. Calcium sulphate, phosphogypsum and calcium carbonate in the amelioration of acid subsoils for root growth. Plant Soil 1997, 192, 37-48. [CrossRef]

49. Venter, H.J. Soil Acidity in the Kakanui Ranges; Fertiliser and Lime Research Centre, Massey University: Palmerston North, New Zealand, 2017; p. 8.

50. Whitley, A.; Moir, J.; Almond, P.; Moot, D. Soil pH and exchangeable aluminium in contrasting New Zealand high and hill country soils. Hill Ctry. Grassl. Res. Pract. Ser. 2016, 16, 169-172.

51. Moir, J.; Moot, D. Medium-term soil pH and exchangeable aluminium response to liming at three high country locations. In Proceedings of the New Zealand Grassland Association Conference, Alexandra, New Zealand, 5-7 November 2014; pp. 41-45.

52. Morton, J.; Gray, M.; Gillingham, A. Soil and pasture responses to lime on dry hill country in central Hawke's Bay, New Zealand. N. Z. J. Agric. Res. 2005, 48, 143-150. [CrossRef]

53. Wheeler, D.; O'Connor, M. Why do pastures respond to lime? In Proceedings of the New Zealand Grassland Association Conference, Nelson, New Zealand, 1998; pp. 57-62.

54. During, C.; Jackson, B.; Dyson, C. Lime effects on hill country: 2. Relation of soil moisture, pH, and aluminium values with pasture yield. N. Z. J. Agric. Res. 1984, 27, 531-535. [CrossRef]

55. McIntosh, P.; Backholm, G. A Reconnaissance Soil Survey of the Otago Uplands [New Zealand]; 0110-649X; Ministry of Primary Industries: Wellington, New Zealand; Invermay Agricultural Research Centre (NZ): Mosgiel, New Zealand, 1981; p. 93.

56. Horsnell, L. The growth of improved pastures on acid soils. 3. Response of lucerne to phosphate as affected by calcium and potassium sulfates and soil aluminium levels. Aust. J. Exp. Agric. 1985, 25, 557-561. [CrossRef]

57. Barrow, N. The effects of $\mathrm{pH}$ on phosphate uptake from the soil. Plant Soil 2017, 410, 401-410. [CrossRef]

58. Al-Enazy, A.-A.; Al-Barakah, F.; Al-Oud, S.; Usman, A. Effect of phosphogypsum application and bacteria co-inoculation on biochemical properties and nutrient availability to maize plants in a saline soil. Arch. Agron. Soil Sci. 2018, 64, 1394-1406. [CrossRef]

59. Curtin, D.; Syers, J. Lime-induced changes in indices of soil phosphate availability. Soil Sci. Soc. Am. J. 2001, 65, 147-152. [CrossRef]

60. Sorn-Srivichai, P.; Tillman, R.W.; Syers, J.K.; Cornforth, I.S. The effect of soil pH on Olsen bicarbonate phosphate values. J. Sci. Food Agric. 1984, 35, 257-264. [CrossRef]

61. Naidu, R.; Syers, J.; Tillman, R.; Kirkman, J. Effect of liming and added phosphate on charge characteristics of acid soils. J. Soil Sci. 1990, 41, 157-164. [CrossRef]

62. Barrow, N. Modelling the effects of pH on phosphate sorption by soils. J. Soil Sci. 1984, 35, 283-297. [CrossRef]

63. McLean, E. Chemistry of soil aluminum. Commun. Soil Sci. Plant Anal. 1976, 7, 619-636. [CrossRef]

64. Haynes, R.; Ludecke, T. Effect of lime and phosphorus applications on concentrations of available nutrients and on $\mathrm{P}, \mathrm{Al}$ and Mn uptake by two pasture legumes in an acid soil. Plant Soil 1981, 62, 117-128. [CrossRef]

65. White, R.; Taylor, A. Effect of $\mathrm{pH}$ on phosphate adsorption and isotopic exchange in acid soils at low and high additions of soluble phosphate. J. Soil Sci. 1977, 28, 48-61. [CrossRef]

66. USDA. Keys to Soil Taxonomy, 12th ed.; United States Department of Agriculture, Natural Resources Conservation Service: Washington, DC, USA, 2014. 
67. Hewitt, A.E. New Zealand Soil Classification; 1172-269X; Manaaki Whenua Press, Landcare Research: Lincoln, New Zealand, 2010.

68. Blackmore, L.; Searle, P.; Daly, B. Methods for Chemical Analysis of Soils; New Zealand Soil Bureau Scientific Report No. 80; Department of Scientific and Industrial Research: Wellington, New Zealand, 1987.

69. Olsen, S.R. Estimation of Available Phosphorus in Soils by Extraction with Sodium Bicarbonate; USDA: Washington, DC, USA, 1954.

70. Saggar, S.; Hedley, M.; White, R. A simplified resin membrane technique for extracting phosphorus from soils. Fertil. Res. 1990, 24, 173-180. [CrossRef]

71. Dick, W.; Tabatabai, M. Determination of Orthophosphate in Aqueous Solutions Containing Labile Organic and Inorganic Phosphorus Compounds 1. J. Environ. Qual. 1977, 6, 82-85. [CrossRef]

72. Bowman, R.; Moir, J. Basic EDTA as an extractant for soil organic phosphorus. Soil Sci. Soc. Am. J. 1993, 57, 1516-1518. [CrossRef]

73. Turner, B.L.; Cade-Menun, B.J.; Condron, L.M.; Newman, S. Extraction of soil organic phosphorus. Talanta 2005, 66, 294-306. [CrossRef]

74. Watkinson, J.; Kear, M. High performance ion chromatography measurement of sulfate in $20 \mathrm{~m}$ M phosphate extracts of soil. Commun. Soil Sci. Plant Anal. 1994, 25, 1015-1033. [CrossRef]

75. Carey, P.; Metherell, A. Rates of release of non-exchangeable potassium in New Zealand soils measured by a modified sodium tetraphenyl-boron method. N. Z. J. Agric. Res. 2003, 46, 185-197. [CrossRef]

76. Keeney, D.; Bremner, J. Comparison and Evaluation of Laboratory Methods of Obtaining an Index of Soil Nitrogen Availability 1. Agron. J. 1966, 58, 498-503. [CrossRef]

77. Hoyt, P.; Nyborg, M. Use of dilute calcium chloride for the extraction of plant-available aluminum and manganese from acid soil. Can. J. Soil Sci. 1972, 52, 163-167. [CrossRef]

78. Brown, I.C. A rapid method of determining exchangeable hydrogen and total exchangeable bases of soils. Soil Sci. 1943, 56, 353-358. [CrossRef]

79. Rayment, G.E.; Higginson, F.R. Australian Laboratory Handbook of Soil and Water Chemical Methods; Inkata Press Pty Ltd.: Melbourne, Australia, 1992; 330p.

80. Roberts, A.; Webb, T.; Morton, J.; O'connor, M.; Edmeades, D. Building a solid foundation-sulphur, phosphorus and potassium requirements for the sedimentary soiIs of North Canterbury. In Proceedings of the New Zealand Grassland Association Conference, Hanmer Springs, New Zealand, 1994; pp. 7-12.

81. Pang, J.; Tibbett, M.; Denton, M.D.; Lambers, H.; Siddique, K.H.; Bolland, M.D.; Revell, C.K.; Ryan, M.H. Variation in seedling growth of 11 perennial legumes in response to phosphorus supply. Plant Soil 2010, 328, 133-143. [CrossRef]

82. Whitley, A.E. Investigations of Soil Extractable Aluminium and Toxicity in New Zealand Soils. Ph.D. Thesis, Lincoln University, Lincoln, New Zealand, 2018.

83. NIST. Standard Reference Material 1573a, Tomato leaves. In Certificate of Analysis; National Institute of Standards and Technology: Gaithersburg, MD, USA, 1995; p. 5.

(C) 2020 by the authors. Licensee MDPI, Basel, Switzerland. This article is an open access article distributed under the terms and conditions of the Creative Commons Attribution (CC BY) license (http://creativecommons.org/licenses/by/4.0/). 